\title{
Verbal and Non-Verbal Expression in Javanese Language of the Coastal Community in Banjar Kemuning Village, Sidoarjo
}

\author{
Umar Chafidhi; Wakit Abdullah Rais; Dwi Purnanto \\ Master Linguistics Department, Universitas Sebelas Maret, Surakarta, Indonesia
}

http://dx.doi.org/10.18415/ijmmu.v6i6.1199

\begin{abstract}
This study reveals all Javanese language categories and expressions of the coastal community of Banjar Kemuning village, Sidoarjo district through the perspective of ethnolinguistic studies. This type of research is descriptive qualitative. Data collection used participatory observation and interview techniques that were collaborated with the recording and recording techniques. This research uses ethnographic methods with the analysis model that is the ethnoscience model. The results of this study indicate that through the mindset and knowledge system of society especially the coastal community of Banjar Kemuning village, it has been found all kinds of Javanese language categories and expressions in their speech expressions in the form of a way of life in terms of livelihoods as fishermen and pond farmers, the names of fishing tools and pond farmers, the names of sea products, a set of terms of offerings and various rituals, mantra or prayers as well as local wisdom of the village community hidden behind verbal and non verbal expressions.
\end{abstract}

Keywords: Linguistic Categories and Expressions; Javanese Language; Sidoarjo Coastal Community; Ethnolinguistics

\section{Introduction}

This study wishes to uncover all Javanese language categories and expressions of the coastal community in Banjar Kemuning village, Sidoarjo district through the perspective of ethnolinguistic studies. The coastal community of Banjar Kemuning village, Sidoarjo regency is located along the eastern coast of the East Java region, where the majority of the people's occupation are fishermen, while some other are pond farmers. According to (Foley, 1997) that ethnolinguistic study is a liguistic branch that pays attention to language position in a broader social and cultural context to advance and maintain cultural practices and social structures. By this view, the ethnolinguistic study enables the researcher to explore the cultural phenomena, demographic and ecological factors affecting the categories and expressions of Javanese language, as well as discover the community's knowledge system (cognitive) that describes the people's world views, ideas, and thoughts manifested in their daily spoken Javanese language. According to Dove cited in (Abdullah, 2016b) that the role of traditional culture is closey linked with the social, economic, and ecologica processes of society. Language is very influential in 
human life because language is not only a determinant in the development of a particular culture of society but language is part of the culture itself. This is in accordance with the opinion Masinambow in (Mardikantoro, 2013) that language occupies a central position in human life because language has multiple aspects, especially biological, social and cultural. Culture is inseparable from the language used in the cultural community itself, inevitably even language is an object that connects how the culture in terms of form, function, and lexical meaning that exists in the culture (Kusumawati, 2016).

Linguistic categories and expressions of vocabulary and words choice use, i.e., expressed by farmers and fishermen communities' life views of either through the implied or explicitly clarify as the cultural bearers of the knowledge systems (cognition) recorded in language as an integral part from the culture. Furthermore, the relationship between Javanese language and their culture exhibited by the fishing community and pond farmers on the coastal area of Banjar Kemuning village, Sedati subdistrict, Sidoarjo regency, practically there are abundant interesting the local wisdom issues which require further discussion from the perspective of ethnolinguistic studies.

Various arguments on the importance of the linguistic categories and expressions study of the Javanese coastal communities in the Banjar Kemuning village of Sidoarjo regency, among others: (1) The community of Banjar Kemuning village as a sub-ethnic of the East Java region. The Javanese language used by the fishermen and pond farmers in Banjar Kemuning village categorically classified as the typical Javanese language of "Suroboyoan" also known as the "Arek". The Arek language is a distinctive icon of the Javanese language spoken by people live in sub area of the East Java region, even though its distribution area covers "Gerbangkertasusila" namely Gresik, Jombang, Mojokerto, Surabaya, Sidoarjo, and Lamongan. Javanese Suroboyoan is popularly known by its speaker's characteristics, harsh and temperamental and egalitarianist, which is observable from the Javanese spoken dialect with a more openly and perceived rude spoke language. Their Javanese language is different from the standard Javanese Surakarta-Yogyakarta dialects. The coastal village of Banjar Kemuning was also visited by fishermen from the outer village area. (2) Data shows Javanese language expressions related to livelihoods as fishermen and pond farmers. (3) There are categories and expressions related to their livelihoods such as the following phrase, "wolong poloh persen wong kene dadi nelayan rong poloh sisane dadi ngurus tambak. Sejarah e mriki iku mboten banjar kemuning tapine turen, tukar guleng kale TNI Juanda akhire dipindah. Biyen mriki iku pantae, daratan semakin tinggi dadine tambak, tambak geser geser dadine gawe omah". eighty percent of the people here work as fishermen and the rest work as pond management \{pond farmers . The origin of the history was not Banjar Kemuning village but Turen village, there was land swap with the Juanda TNI it was finally moved. In the past this area was a beach, the land became more and more a pond, the pond changed into and finally housese were built '). There is also related to prayer (by the fishing community is additionally considered a mantra), namely, Bismillah niat budhal njupuk jatah saking pengeran, budhal selamet moleh selamet lillahi ta'ala' Bismillah in the name of Allah, I intentionally go to take part / livelihood from Allah, I wish go to the journey safely return home safely).

Banjar Kemuning villagers cannot deny the observing cultural traditions to preserve the ancestral heritage. They believe that in every corner of the room there are guardians, they call them "danyang segoro" ('the sea guardian'). Thus, the community in each of their lives, at the time before and after undergoing activities as fishermen and fish farmers will hold a ritual salvation "bancaan / slametan"with a hope to be blessed with salvation in each of their steps. Ethnolinguistically this study was conducted to seek out all the linguistic events of the coastal communities live in Banjar Kemuning village, additionally to uncover the people's worldview, knowledge system, and people's life towards the macro- and microcosmos. The problems elaborated in this study concern about the linguistic categories and expressions of the Javanese coastal communities in the Banjar Kemuning village, Sidoarjo district. 
Ethnolinguistic studies aimed to uncover the patterns of cultural frameworks and local values that stand to be elements of the local wisdom manifested in a particular community's language and culture. According to Koentjaraningrat cited in (Komariyah, 2018) says that culture is on generally passed on more carefully through language; means language is the main vehicle for inheritance, as well as cultural development. In the perspective of anthropology, language is part of a culture. On the contrary, culture in general is passed more carefully through language. Therefore, language is the main vehicle for cultural inheritance and development. This is in line with the opinion Duranti in (Wulandari, Marsono, \& Suhandono, 2018) which states that describing a culture is the same as describing language. On the other hand (Foley, 1997) that suggests ethnolinguistics (anthropological linguistics), as a branch of linguistics that pays attention to language position in the wider social and cultural contexts to advance and maintain cultural practices and social structures. This is understood more broadly because language is associated with the existing social and culture in people's lives. According to Ahimsa in (Baehaqie, 2014) states that ethnolinguistics is a very interesting field of study because it is in this field that something very important can be found, namely the process of cultural formation and its relation to language, as well as the culture that is formed is constantly undergoing changes, both realized and not by supporters of that culture, as reflected in their language. Other opinions expressed by Sibarani in (Putro, Fernandez, \& Abdullah, 2016) that anthropolinguistics is a branch of linguistics that studies variation and the use of language in relation to time development, differences place of communication, kinship system, influence of ethnic habits, beliefs, ethics language, customs, and other cultural patterns of a linguistic tribe.

At the beginning of its development, there was no distinction between sociolinguistic, ethnolinguistic and anthropolingistic studies since all of these studies were related to language studies as part of certain societies, cultures, and ethnicities. However, due to its development, finally each of these studies specializes in different aspects of language use. Sociolinguistics is more specialized in the study of language variation with the diversity of its speakers, while anthropolinguistics and ethnolinguistics are more directed at communication patterns of language behavior based on the culture of its speakers (Sukarno cited in (Sugianto, 2017).

Local wisdom is a life value system inherited from one generation to the next either in the form of religion, culture or customs which are generally oral realized into a society's social system. People always realize everything they feel and think through language expression. Therefore, the culture of the community always colors the language it uses. Javanese people in particular have local wisdom in their daily culture. In the Endraswara's opinion in (Mardikantoro, 2016) that local wisdom is a pillar of thought based on the character of tradition. The local wisdom found among the community is the result of an inherited adaptation process passed through generations in a very long period of time to an environment commonly inhabited or the environment where interactions occur frequently. The local wisdom, or in a foreign language, is often aconceptualized as "local knowledge" or "Local genious", which is a life view, science, and various life strategies tangible activities carried out by the local community to cope with various problems in part of fulfilling their daily needs (Mashadi in (Unsriana, 2013). According Mahsun in (Abdullah, 2016a) mentioning many ways to uncover the culture behavior (of indigenous) society, one of them is through viewing the language use. Conceptually, local wisdom is part of culture. This was agreed by Haryati in (Brata, 2016) by local wisdom that is entirely related, can be considered the same as cultural identity that can be interpreted with cultural identity or belief according to the nation.

The term ethnoscience is also acknowledged by others as The New Ethnhography or Cognitive Anthropology (Spradley, 1997) which meant to reveal the human knowledge aspects which guide individuals' behavior in everyday life. It pertains about ethnics, knowledge of language is the easiest way to arrive at a community's knowledge system Ahimsa-Putra cited in (Abdullah, 2011).The macrolinguistic dimension can enrich the microlinguistic study of the ethnolinguistic study. Through ethnolinguistic study, it enables us to optimally explore the linguistic-anthropological "sense" in exploring the languages 
of the remote communities Fernandez cited in (Abdullah, 2011). Language enables us to uncover the the speakers' culture by examining the linguistic elements of the vocabulary, phrases, sentences and discourse.Ethnolinguistics concerns the exploration on language use in a broader sense as a cultural expression which prevails among the living society. Thus, the microlinguistic aspect plays a significant role a complementary to the micro dimension of the ethnolingistic studies.

The language use that develops in its local community is closely tied to the speaker's culture. There is a view that, all languages in the world are considered perfect if only they are able to describe the residing culture. Then the cultural meaning of a language is a meaning that typically expresses the typical cultural elements and cultural requirements of the cultural aspects. The cultural meaning is subsequently distinctive for it is almost impossible to translate them into other languages (Subroto, 2011). The purpose of this cultural semantics is meant to explore the meanings reflected from the verbal and non verbal expressions through the language of a society to gain a complete understanding of the culture prevailing in that society. In the socio-cultural aspects of a particular community life associated with the various cultural events and customs. It is simply understable that that culture as the final determinant of meaning, or the meaning of language is entirely determined by the cultural context in which the language is used Frawley, 1992, p. 45; Subroto, 2011, p. 17 cited in (Abdullah, 2013).

Literature studies related to previous research on Javanese language and culture as follows, Linguistic categories and Javanese Expression of Fishermen Community in Kebumen (Abdullah, 2011), Local Wisdom of Language and Culture of the Purworejo Coast Fishermen Community (Bagiya, 2016), and Local Wisdom of the Javanese Language and Culture of the Fishermen Community in Kebumen (Abdullah, 2017).

\section{Method}

The study on Linguistic Categories and Expressions in Javanese Coastal Communities in Banjar Kemuning Village, Sidoarjo Regency is a typical descriptive-qualitative study. This research method provides us guidance to reveal all kinds of the needed information elaborated through carefully descriptive report Sutopo in (Abdullah, 2017). The data covers the various oral data in language expression communicated by the fishermen and pond farmers. The data were divided into two types, the primary and secondary data. The data are essentially the research objects, the reality occurs at the field which become the focuse of the research, typically it includes places, participants, and events surrounding the the research focus (Santosa, 2017). The data which partly classified as the primary data are (1) oral data of vocabulary, phrases, clauses or sentences forms linguistically reflected in both verbal and nonverbal expressions of the coastal community language; (2) research data obtained from the selected informants and key informants; (3) research data are the language and cultural events occur as partly become the fishing community and pond farmers activities.

The primary data were taken from the primary data sources, among others: (1) folklore, public speech (2) selected speakers who truly capable of understanding both verbal and nonverbal expressions among the fishermen and fish farmers in Banjar kemuning village, and (3) various languages and cultural events occur in the community's socio-cultural contexts. The secondary data includes various data documents of articles, reference books and others related to the language and cultural phenomena of the fishermen and fish farmers, more specifically things related to the studied area. Thus finally, various written documents about the language and cultural phenomena of fishermen and pond farmers, especially those related to Banjar Kemuning village of Sidoarjo regency. The classified data discussed in this study are as follows; the name of the fish, the name of the fishing gear, the name of the boat, the terms used in 
ritual or offerings, spells or prayers and the residing local wisdom. The data sources of this study were selected informants, fishing communities and pond farmers and community language utterances.

Data collection technique used the participant observation technique on several selected informants, they were then interviewed. In addition to ethnographic note which follows (Spradley, 1997) to propose the descriptive, structural and contrast questions. The interview technique used the indepth interviewing method. The data analysis technique followed the ethnographic methods which follows the ethnoscience model of analysis. Data validity technique applied the triangulation, and complete observation on the key informants Sutopo in (Abdullah, 2017)

\section{Finding and Discussion}

\subsection{The View of Life of Coastal Communities Is Related to Livelihoods}

The community is responding to ecological changes in their area where the land is getting higher and the sea is drifting away, consequently such environmental condition drive the pond farmers to fulfill their daily needs. This is in liine with the community's expression "Biyen mriki iku pantae, daratan semakin tinggi dadine tambak, tambak geser geser dadine gawe omah" ('Formerly here was a stretch of beach, the higher land was made into ponds, shifted ponds eventually turned into houses'). Other expressions are Jaman biyen cumak nyager tok nang laut, saiki meluas njaring urang, njaring begog, njarong dorang" ('In ancient times it was only a fisherman only nyager (fish hunting) in the sea, now they have expanded to catch for shrimp, begog and dorang fish'). This is a form of community motivation to always innovate in order to lead a prosperous life, although the their life practices seemed traditional, however, they keep wishing for more developing. "Urip nang kene iku yoo kadang eco, kadang mboten, keadaane yoo ngene iki, nyambut jeragan, perahu nyambut jeragan, sing penting cukup" ('life here is sometimes good, sometimes the other way around. The situation has always been like this, rent to skipper, the boat was a rent from skipper, most importantly it is enough'). The community's view regarding the life phrase illustrates that they prefer sufficient income by notimposing themselves on higher targets.

\subsection{The Names of Fish and Fish Pond}

The high commodity of fishing community in Banjar Kemuning village is the sea products in the form of kerang [kəray] shellfish and 'urang' [uray] shrimp. There are also those who use land as ponds, local people cultivate bandeng [bandəy] milkfish and 'urang' [uray] shrimp ponds. Even so there are some communities who have also managed to get catches in the form of dorang fish, begog [bəg0g] begog fish, laosan [la0san] laosan fish, snapper fish, tuna fish, grouper fish, kpiting [kpetey] crab and others. The picture beside is kerang [kəray] shellfish as a main commodity of the east Java coastal community in Banjar

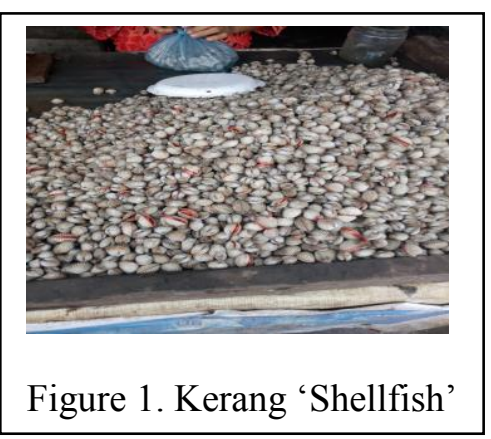
Kemuning village of Sidoarjo. The mayority of villagers still survive as fisherman who are a legacy from their ancestors, although the ecological situation in the village has changed. They caught kerang [koray] shellfish with a simple device called 'Garit' [garct] made of stainless steel which they made themselves. The tool is maade with a large size so that it can catch shellfish in large numbers because it is proportional to the energy expended. Like the following verbal expression "garet ditarik kudu kuat sampek tangan 
kapalen ben oleh kerang sing akeh", "the garit must be pulled as hard as possible until the palms are rough, in order to get a lot of shellfish'. The expression represents their simple view of life utilizing materials to self assemble the device with a large size in order to obtains satisfactory result.

\subsection{The Names of Boat Parts}

The fishing community of Banjar Kemuning village has their own understanding regarding the naming of each boat. Ie., a boat owner would name his boat with "Semar Mesem", the owner hopes that his boat in meantime would attract the fish attention and the like, thus the catch would be abundant. There are also those who would name their boats as they like, even film figures and their children's names. This phenomenon becomes their cognitive culture which is reflected in verbal expressions in naming their boat. This has an impact on their confidence when

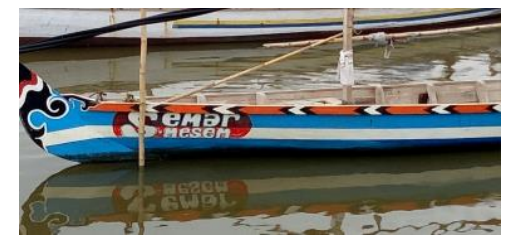

Figure 2. Fishermen's Boat nyang laut 'goes out to sea' and becomes a source of confidence in their activities.

As for the names of the boat parts the so called "Centik" (the front and rear end of the boat), "Plipitan" (the edge of the boat), " Tatapan " (the footrest on the boat), "Tonggol" (mast of the boat), "Pulangan" (the wooden part as a barrier between the captain and crew), "Bangkalan" (the wooden part as a barrier and prop for diesel engines), "Gadingan" (a piece of wood to sustain the board as a footrest on riding a boat).

\subsection{The Names of Fishing Tools and Pond}

The Javanese language categories and expressions of the fishing community are identifiable as follows (1) 'Cager' [cagər] a collection of teak boards that use the method of catching fish by damming water sea at high tide assisted with a tool called Waring. Lexically cager has a meaning that is a fork (pathokan) is embedded into a weak pole (marker) that is planted on the ground (Poerwadarminto, 1939). 'Garit'[garet] a tool to capture shells made of stanless, consists of other supporting tools namely pengirit [pəyiret] the theif rope or called a slap rope, a tool to capture shellfish. (3) 'Trol / Reg' a tool that is pulled out by boat. This tool is also a

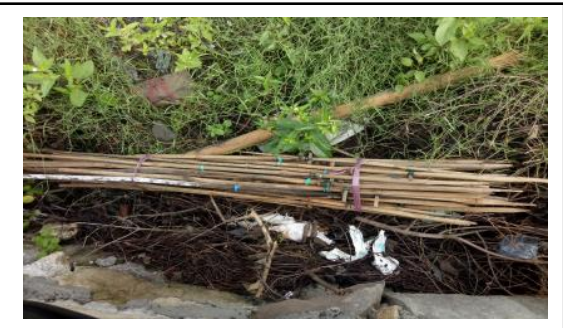

Figure 3. Walesan Tool modified tool made from waring which is formed like serok [scrO?]. (4) Jaring [jarcy] the fishing community in Banjar Kemuning village divides the types of net tools into two types, namely fishing nets and shrimp nets. Both types of nets are distinguished by the basic shape of the net or knitted nets. That is because the size of the fish and shrimp are different. Lexically the net has meaning a tool made of large knits is used to find fish and birds (Poerwadarminto, 1939). (5) Walesan [waləsan] the fisrt tool for crab fishing fishermen found by researcher at the study site was a welasan. The word walesan is a type of word monomorfemic which has free meaning which is a gagang pancing 'fishing rod'. Lexically walesan has meaning 'garan sing mentul (pancing' a flexible fishing rod. Other meaning is a crab fishing tool made of bamboo in which the bait is pierced using that tool. (6) 'Bencet / Badong' [boncet] this tool is a supporting tool for the walesan tools previously described above. Bencet [bəncet] is a trap for crabs when approaching a walesan that has been installed with bait in the form of a small fish. While the tools used by pond farmers are as follows (1) the first tool is prayang [prayan], the tool is made of woven bamboo shaped like a tube as a fish shelter when harvested on a pond. The pond farmer's expression is as follows 
'prayang niku asli kayu ori ngoten awes' 'prayang tools are original from old bamboo called is Ori and very expensive. (2) The next tool is Pelong and Wede. These tools collaborate with each other in ponds to herd fish and shrimp. Wede tool also requires net material such as waring in use. (3) The last tool is Waring. This tool is known a net material by fish finders. Farmers use this material as a substitute for features made of wood and are considered heavy when used. This tool has helped pond farmers to work and made it very efficient to use when 'entas ulam karo urang' harvesting fishand shrimp.

\subsection{The Names of Terms of Offerings 'Sajen [sajen]' and Rituals}

The Fishermen and pond farmers communities in Banjar Kemuning village preserve their inherited cultural traditions from time to time, ie., the sea salvation ceremony called "nyadran" or sea alms. In addition to use of varied types of "sajen" ('offerings') were served in the ceremony such as "pitik panggang" ('roasted chicken') also the community often time serve " wedhus sak ekor" ("a goat"). Both of them were taken to the middle of the sea with the accompaniment of a boat belong to the other Banjar Kemuning native residents. At the time the offering arrived in the middle of the sea it will be dissolved into the sea as a gratitude manifestation for the sea results during the fishing. The other "sajen" ("offerings") served are reflected in following nonverbal expressions below:

1) "klopo" ("coconut"), they chose the old coconut in this offering, it was not separated from the philosophy of the coconut itself. It is chosen as parable, we must not forget our parents in all activities. Parental prayer is needed for the success of our activities. As reflected in the following expression below, "kenopo kok klopo tuwo? Senajan opo ae ojok sampek lali marang wong tuwo loro. Jenenge klopo iku buah sing apik, banyune dibungkus daging klopo, daging dibungkus kulit tipis, kulit tipis dibungkus sabut, sabut dibungkus kulit klopo sing tebel. Iki maknane banyu klop iku akeh khasiate". "why choose old coconut? Whatever the situation, we must not forget our parents. Coconut fruit is good, coconut water is coated or protected by coconut meat, coconut meat is coated by thin skin, thin skin is coated by coconut fiber, coconut fiber is coated by thick skin. This means that coconut water has good properties so that it is well protected.

2) "rice", people choose rice in the offerings with the belief that rice is the main daily food source. As in the following expession "beras damel pancingan rejeki" "rice is used to attract sustenance'.

3) "kembang tulak" ("tulak flower"), the community gave this name with the intention for resist a danger (fend of all kinds of danger).

4) "gedang rojo" ("plantain"). This is a parable of a king. The king has a high degree and is the desire of the people in life.

The activity of Nyadran ' alms sea' is routinely carried out each year, namely in the month of Sya'ban before the arrival of Ramadan. This was carried out as a village cleansing and alms-giving of sea products to show the gratitude to the God for all the blessing bestowed on. As for other traditions observed by the coastal community living in Banjar Kemuning village where the majority of the population embraces Islam. The people rountinly hold "Yasinan" in every Thursday evening (reciting Surah Yasin, a chapter in the Qur'an), "Tahlilan" (reciting a series of congregational gatherings and reciting prayers for the already preceeded ancestors), "Ratiban" (reciting shalawat or prayer to the Prophet Muhammad), "Jam'iyyaan" (reading a number of series of shalawat to the Prophet). 


\subsection{Mantra or Prayer}

Banjar Kemuning coastal community well-understood that a mantra or chant is indetical to $d u^{\prime} a$ praying due to the strong influence of Islamic teaching leads the cultural practices to be well-preserved. The majority of villagers compared to minority residents consider this mystical mantra to be non-existent but some individuals are still influenced by Javanism teachings brought by "Sabdo Darmo" or the Kejawen Islamic school.

Some of the commonly read prayer expressions is on leaving for the sea "Bismillah, mugo gede gede ambek akeh hasile " ('Bismillah by the name of Allah, may I be bestowed with a great (fish or shrimp) and many results). The expression has been consistently begun with reading the phrase "Basmalah", that the community believe the saying brings a lot of positive effect, it is indeed a spirit of optimism and a subjugation to the God's provisions for the results after the optimally done effort. There are other versions of expressions that are identical to the prior, which is "Robbana, telek rejeqi, budhal ' (' Our Lord, I seek to your blessing, I therefore depart'). Having chanted this prayer, which is further considered as an Islamic mantra, believing the Almighty Allah is all everything the believers should do, it enhances their physical and spiritual strength and until they return home safe.

\subsection{Local Wisdom}

This part discusses the values reflected from local wisdom practiced by the coastal community in Banjar Kemuning village, one of which is manifested in their belief, that everything in the earth and heaven has been set by the Almighty Allah and therefore each creature should submit to the power of Allah, this was recorded in people's verbal expression, " Agomo ten mriki insha Allah alhamdulillah sampun sae, wes pengeran tok sing dipercoyo, gak onok sing diwedeni kecuali iku tok" ("Religion here is already good insha Allah, thank God. The God (Allah) alone is trusted, no one is feared except Him alone. "This illustrates that the coastal communities in Banjar Kemuning village embrace Islamic teaching and belief as high spiritual aspects, that they practice and maintain them in daily bases in addition to preserve the prevailing culture.

A number of people in the community also in the supernatural beings, guardians in each part of places in the earth, however, they return and fully trust the God to be guided in living a life, the following expression recorded people's worldview "Sedoyo tempat nggeh wonten sing nunggu, mboten ten laut tok, ten alas nggeh wonten, nggeh ningali tiange mawon"'('all places are guarded, not only in the sea, in the forest yes certainly there are, only it depends on ourselves'). Bearing the truth on the local community all living and unseen is the creation of the God. They believe in all corners where there must be guardian who occupies and resides, then as humans continue to maintain harmony by not disturbing or transgressing and respect each other as fellow creatures.

\section{Conclusion}

The discussion about the study of the linguistic categories and expressions $t$ in Javanese, the coastal community in Banjar Kemuning village, Sidoarjo district conclude that the community's lifeviews, thoughts, perception and knowledge system, all kinds of Javanese language categories and expressions were found the community's daily language use on ie., carrying livelihood as fishermen and pond farmers, all the wisdom covers the naming system of sea fishing pond farmers' equipments, the naming of the seafood types, a set of offerings and various rituals, matra, chant or prayers, in addition to 
the hidden local wisdom of the village community manifested through their verbal expressions. This east coast community of Java still maintains traditional tools in their activities as fisherman dan pond farmers. Through their verbal and non-verbal expressions that are reflected in all their activities as fisherman and pond farmers, their mindset and way of life are found that still uphold the values of Javanese philosophy in addition to the religion they believed in namely is Islam. Religious ethical values combined with the values of Javanese philosophy seem harmonious in social life in the east coast of Java. The verbal and non-verbal expressions of Banjar Kemuning villagers illustrate the culture inherent in their simple lives and preserving cultural practices through Javanese language expressions that they understand.

Hopefully this study can significantly contribute to ethnolinguistic studies, especially in terms of language use in coastal communities as the research object. Having successfully explored the local wisdom manifested in Javanese language and cultural expressions, the study objectively not only wishes to preserve the inherited cultural traditions and language expressions of the community, however, this also would like to invite the local government for its support in maintaining the local genious and language from extinction. This study suggests the future research to be able to deeply observe the integrated aspects between the language use in and the society in a more comprehensive way.

\section{References}

Abdullah, W. (2011). Kategori dan Ekspresi Bahasa Jawa Komunitas Nelayan di Pesisir Selatan Kebumen (Kajian Etnolinguistik). Jurnal Penelitian Budaya Etnik (Etnografi), 11(01), 54-64.

Abdullah, W. (2013). Etnolinguistk: Teori, Metode dan Aplikasinya. Surakarta: Jurusan Sastra Daerah, FIB, Universitas Sebelas Maret.

Abdullah, W. (2016a). Ethnoliguistic Study of Local Wisdom in Ex-Residency of Surakarta. Humaniora, 28(3), 279-289. https://doi.org/10.22146/jh.v28i3.22279

Abdullah, W. (2016b). Javanese Language and Culture in the Expression of Kebo Bule in Surakarta: An Ethnolinguistic Study. Komunitas, 8(2), 285-294. https://doi.org/10.15294/komunitas.v8i2.7195.

Abdullah, W. (2017). Kearifan Lokal dalam Bahasa dan Budaya Jawa: studi kasus Masyarakat Kebumen Jawa Tengah (Kajian Etnolinguistik). (01 ed.; Sumarwati, ed.). Surakarta: UNS Press.

Baehaqie, I. (2014). Jenang Mancawarna Sebagai Simbol Multikulturalisme Masyarakat Jawa. Jurnal Komunitas: Research and Learning in Sociology and Anthropology, 6(1), 180-188. https://doi.org/10.15294/komunitas.v6i1.2953.

Bagiya. (2016). Kearifan Lokal Bahasa Dan Budaya Masyarakat Nelayan Pantai SELATAN Kabupaten Purworejo. JURNAL BAHTERA, 03(5), 22-39.

Brata, I. B. (2016). Kearifan Budaya Lokal Perekat Identitas Bangsa. Bakti Saraswati, 05(01), 9-16. https://doi.org/10.1007/s11104-008-9614-4.

Foley, W.(1997). Anthropological Linguistics An Introduction. University of Sydney: Blackwell Publisher. 
Komariyah, S. (2018). Leksikon Peralatan Rumah Tangga Berbahan Bambu Di Kabupaten Magetan (Kajian Etnolinguistik). Paramasastra, 5(1), 1-20. https://doi.org/10.26740/parama.v5i1.2725.

Kusumawati, S. (2016). Leksikon Budaya Dalam Ungkapan Peribahasa Sunda (Kajian Antropolinguistik). Lokabasa,07(01), 87-93. Retrieved from http://ejournal.upi.edu/index.php/lokabasa/index

Mardikantoro, H. B. (2013). Bahasa Jawa Sebagai Pengungkap Kearifan Lokal Masyarakat Samin di kabupaten Blora. Komunitas, 5(2), 197-207. https://doi.org/10.15294/komunitas.v7i1.3622.

Mardikantoro, H. B. (2016). Satuan Lingual Pengungkap Kearifan Lokal Dalam Pelestarian Lingkungan. Bahasa Dan Seni: Jurnal Bahasa, Sastra, Seni Dan Pengajarannya, 44(1), 047-059. https://doi.org/10.17977/um015v44i12016p047.

Putro, D. B. W., Fernandez, I. Y., \& Abdullah, W. (2016). Perilaku Verbal Dan Nonverbal Dalam Ranah Kesehatan Pada Masyarakat Di Dusun Tambran Kidul Kecamatan Semin Kabupaten Gunungkidul (Kajian Etnolinguistik). PRASASTI: Journal of Linguistics, 1(1), 44-60. https://doi.org/10.20961/prasasti.v1i1.548.

Santosa, R. (2017). Metode Penelitian Kualitatif Kebahasaan (1st ed.; D. Purnanto, ed.). Surakarta: UNS Press.

Spradley, J. P. (1997). The Ethnographic Interview (Metode Etnografi) (M. Z. Alizabeth, ed.). Yogyakarta: Tiara Wacana.

Subroto, E. (2011). Pengantar Studi Semantik dan Pragmatik (1st ed.; M. Rohmadi, ed.). Surakarta: Cakrawala Media.

Sugianto, A. (2017). Etnolinguistik Teori dan Praktik (S. H. Nata, ed.). Ponorogo: CV. Nata Karya.

Unsriana, L. (2013). Nilai Kearifan Lokal dalam Cerita Rakyat Jepang (Minwa). Humaniora, 4(1), 310. https://doi.org/10.21512/humaniora.v4i1.3441.

Wulandari, A., Marsono, \& Suhandono. (2018). Pandangan Penutur Bahasa Jawa terhadap Cacar: Kajian Etnolinguistik. Mozaik Humaniora, 18(1), 15-32. https://doi.org/10.20473/MH.V18I1.9883

\section{Copyrights}

Copyright for this article is retained by the author(s), with first publication rights granted to the journal.

This is an open-access article distributed under the terms and conditions of the Creative Commons Attribution license (http://creativecommons.org/licenses/by/4.0/). 